\title{
The Effect Of Corporate Social Responsibility On Brand Awareness: The Case Study Of PT. Unilever Indonesia And Non-Governmental Organization (NGO) Spektra Surabaya
}

\author{
Habibi Dinil Haq
}

nstansi Penulis, Alamat Penulis, Kota, Kode Pos, Negara

\begin{tabular}{|c|c|}
\hline INFO ARTIKEL & Abstract \\
\hline $\begin{array}{l}\text { Sejarah Artikel: } \\
\text { Diterima : } 2021 \\
\text { Diperbaiki : } 2021 \\
\text { Disetujui : } 2021 \\
\text { Keywords: } \\
\text { Corporate Social Responsibility; } \\
\text { Brand Awareness; Non- } \\
\text { Governmental } \quad \text { Organization; } \\
\text { Business Ethics. }\end{array}$ & $\begin{array}{l}\text { This research is motivated by the increasing number of companies using corporate } \\
\text { social responsibility as a marketing strategy by involving the dimensions of business } \\
\text { ethics and social impact around them to form a good image for the company. This study } \\
\text { aims to determine the effect of corporate social responsibility on corporate image. This } \\
\text { study uses a case study of PT Unilever Indonesia's corporate social responsibility } \\
\text { collaboration with the Non-Governmental Organization (NGO) Spektra Surabaya in } \\
\text { the form of the Gerakan Sikat Gigi Pagi Malam in ten sub-districts in Nganjuk } \\
\text { Regency in mid 2010-2011. This study uses Corporate Social Responsibility (CSR) } \\
\text { model as the analysis framework which consists of Community Support (X1), } \\
\text { Diversity (X2), Employee Support (X3), Environment (X4), Non-US Operations / Not } \\
\text { Only Operate in the Country of Origin (X5), and Products (X6) either jointly or } \\
\text { partially on the company's image, as well as knowing which variables have dominant } \\
\text { influence on the company's image. The type of research used in this research is } \\
\text { explanatory research and the research method used is quantitative with the Slovin } \\
\text { formula and purposive sampling technique. }\end{array}$ \\
\hline & Abstraks \\
\hline $\begin{array}{l}\text { Kata Kunci: } \\
\text { Corporate Social Responsibility; } \\
\text { Brand Awareness; Non- } \\
\text { Governmental Organization; } \\
\text { Business Ethics. } \\
\text { DOI: }\end{array}$ & $\begin{array}{l}\text { Penelitian ini dilatarbelakangi dengan semakin banyaknya perusahaan } \\
\text { menggunakan tanggung jawab sosial perusahaan sebagai strategi pemasaran } \\
\text { dengan melibatkan dimensi etika bisnis dan dampak sosial di sekitar untuk } \\
\text { membentuk citra yang baik bagi perusahaan. Penelitian ini bertujuan untuk } \\
\text { mengetahui pengaruh tanggung jawab sosial perusahaan terhadap citra } \\
\text { perusahaan. Penelitian ini menggunakan studi kasus kerjasama tanggung } \\
\text { jawab sosial perusahaan PT Unilever Indonesia dengan Lembaga Swadaya } \\
\text { Masyarakat (LSM) Spektra Surabaya dalam bentuk Gerakan Sikat Gigi Pagi } \\
\text { Malam di sepuluh kecamatan di Kabupaten Nganjuk pada medio 2010-2011. } \\
\text { Penelitian ini menggunakan model kerangka analisis Corporate Social } \\
\text { Responsibility(CSR) yang terdiri dari Community Support/Dukungan } \\
\text { Masyarakat (X1), Diversity/Membedakan (X2), Employee Support/Dukungan } \\
\text { Karyawan (X3), Environment/Lingkungan (X4), Non-U.S Operations/Tidak } \\
\text { Hanya Beroperasi di Negara Asal (X5), dan Product/Produk (X6) baik } \\
\text { secara bersama-sama maupun secara parsial terhadap citra perusahaan, serta } \\
\text { mengetahui variabel mana yang berpengaruh dominan terhadap citra } \\
\text { perusahaan. Jenis penelitian yang digunakan dalam penelitian ini adalah } \\
\text { explanatory research serta metode penelitian yang dipakai adalah kuantitatif } \\
\text { dengan rumus slovin dan teknik purposive sampling. }\end{array}$ \\
\hline $\begin{array}{l}\text { Korespondensi: } \\
\text { Nama: Habibi Dinil Haq } \\
\text { Email: habibidh1@gmail.com }\end{array}$ & $\begin{array}{l}\text { ISSN: } 2355-9643 \text { (print) } \\
\text { ISSN: } 2460-3775 \text { (online) }\end{array}$ \\
\hline
\end{tabular}




\section{Introduction}

About 50 years ago, Howard R. Bowen argued that business people had an obligation to pursue a policy and make decisions or carry out various actions in accordance with the goals and values of society (Wartick and Cochran, in Solihin, 2008: 1). Bowen's opinion has provided a basic framework for the development of the concept of social responsibility.

Meanwhile, according to Suhandari M. Putri (in Untung, 2008: 1) Corporate Social Responsibility (CSR) is the commitment of the company or the business world to contribute to sustainable economic development by paying attention to corporate social responsibility and emphasizing the balance between attention to economic, social aspects, and the environment. What is unfortunate is that there are still companies that perceive Corporate Social Responsibility (CSR) as part of a cost or reactive action to anticipate community rejection of the environment. Some companies are able to elevate their Corporate Social Responsibility (CSR) status to a higher level by making it an effort of brand building and corporate image. However, these efforts are rarely used as part of corporate strategic planning.

Today, many companies or organizations understand the need to pay enough attention to build a favorable image for a company is not only by letting go of the formation of a negative public impression. One example of a company that uses a Corporate Social Responsibility (CSR) strategy is PT. Unilever Indonesia Tbk (hereinafter referred to as PT. Unilever). PT. Unilever as one of the largest multinational companies in Indonesia has started its Corporate Social Responsibility (CSR) program in 2001 until now. This is proven by the many awards received by PT Unilever Indonesia, such as the world-class Energy Globe Award for saving the Brantas river in 2008, the international Green Apple Award in the Environment Best Practice category at the end of 2007, as well as bringing the MDG's Award at that time (www.mediaindonesia.com).

Interestingly, the success of PT. Unilever Indonesia in carrying out CSR and obtaining the various titles above is due to cooperation with various parties, such as non-governmental organizations (NGOs). One of the important partners for Unilever is the NGO SPeKTRA (Study and Development of People's Empowerment) in East Java. In East Java, many people say that Unilever and LSM Spektra have achieved a lot of success in implementing CSR. Based on the description above, the researcher is encouraged to conduct on "The Effect of Corporate Social Responsibility on Image (Survey of Corporate Social Responsibility (CSR) Recipients of PT. Unilever Indonesia Collaborating with the NGO SPeKTRA in the Form of Morning Night Toothbrush Movement in 10 Districts of Nganjuk Regency. ) ".

\section{Theoretical Framework}

a. The Concept of CSR

The concept of Corporate Social Responsibility (CSR) is inseparable from the context of the time when this concept was developed and various factors that occurred in the internal and external environment of the company that influenced the development of the concept of Corporate Social Responsibility (CSR). The concept of Corporate Social Responsibility (CSR) was rolled out after realizing that what the company actually has to pay attention to is not only shareholders, so that the company does not merely make a profit, increase share prices, and the like. There are other parties outside of shareholders that must be considered, such as employees, the environment, consumers, government, suppliers and so on. The idea of implementing Corporate Social Responsibility (CSR) is not accepted by all groups. The concept of Corporate Social Responsibility (CSR) can be said to be always controversial. Some parties really like and support its application widely and some others are the opposite. The term corporate social responsibility is often criticized as being too philanthropic, which only involves short-term social programs and the giving of money or goods from the company to a group of community members. In a more theoretical and systematic manner, Carrol in Solihin (2008: 21-22) provides a logical justification for why a company needs to implement Corporate Social Responsibility (CSR) for the surrounding community as follows:

a. Economic Responsibilities

The main social responsibility of companies is the responsibility of the economy because business institutions consist of economic activities that produce goods and services for the community profitably.

b. Legal responsibilities

The community hopes that business is carried out by complying with applicable laws and regulations in which the laws and regulations 
are essentially made by the community through the legislative body. For example, obedience to companies in paying taxes, obeying labor laws, and so on are the company's legal responsibilities.

c. Ethical responsibilities

The community expects the company to conduct business ethically. According to Epstein (1989: 584-585), business ethics shows moral reflection carried out by business people individually and institutionally (organizations) to assess an issue where this assessment is a choice, there is value that develops in a society. Through this choice of values, individuals or organizations will provide an assessment of whether something that is done is right or wrong, fair or not, and has utility or not.

d. Discretionary responsibilities (philanthropic responsibilities)

The community hopes that the company's existence can provide benefits to them. The company fulfills this public expectation through various philanthropic programs, the aim of which is to improve the same quality of life.

b. CSR Model

Sen and Bhattacharya (2001: 112) identified six main things included in Corporate Social Responsibility (CSR), namely:

a. Community support; including support for programs in education, health, arts, and so on.

b. Diversity; is the company's policy not to differentiate between consumers and prospective workers in terms of gender, physical (disability), or into certain races. In this study, the indicators used were in terms of gender and certain races. Physical (disabilities) are not included in this indicator because the Corporate Social Responsibility (CSR) program does not involve physically disabled people.

c. Employee support; in the form of protection for workers, providing incentives, and rewards and guarantees of work safety.

d. Environment; create a healthy and safe environment, manage waste properly, create products that are environmentally friendly and others.

e. Non-U.S operations (not only operating in the country of origin); are companies that are responsible for providing CSR activities that are carried out outside the country where the company is located and even in countries that have human rights problems or conflict areas. f. Product (product); the company is obliged to make products that are safe for health, do not cheat, conduct research and product development continuously and use recycled packaging.

Companies can apply one or all of the forms of Corporate Social Responsibility (CSR) mentioned above. The intense competition makes companies hope that this Corporate Social Responsibility (CSR) activity will help companies to provide adding value to customers and increase their loyalty to the company's products. In order to make sure activities on Corporate Social Responsibility (CSR) are truly effective, companies must identify the needs and understanding of the community about Corporate Social Responsibility (CSR) activities and also carefully estimate the resources needed for this program.

c. Brand

According to Bill Canton (in Soemirat and Ardianto, 2003: 111) says that image is "image: the impression, the feeling, the conception which the public has of a company; a conciously created impression of an object, person or organization"

The definition of image according to Jefkins (in Soemirat and Ardianto, 2003: 114) is an impression that is obtained based on one's knowledge and understanding of facts or reality. According to Rakhmat (in Soemirat and Ardianto, 2003: 114) states that image is a description of reality and does not have to correspond to reality, an image is a world according to perception. Thus it can be said that image is the public's perception of something. If something is in the form of an organization or company, it is called a corporate image; if the product is called a product image; if the brandis called a brand image; and self image.

Nimpoeno (in Soemirat and Ardianto, 2003: 115) says that this brand formation model shows how stimuli originating from outside are organized and affect responses. Stimulus (stimulation) given to individuals can be accepted or rejected. If the stimulus is rejected, the next process will not run, this indicates that the stimulus is not effective in influencing the individual because there is no attention from the individual. Conversely, if the stimulus is received by the individual, it means that there is communication and attention from the organism, so the next process can run. If the stimulus gets attention, the individual will try to understand the stimulus. Perception is defined as the result of 
observations of environmental elements associated with a process of meaning or the individual will give meaning to a stimulus. Individual perceptions will be positive if the information provided by stimuli can fulfill individual cognition.

\section{Research Framework}

Independent variables are variables that affect or cause changes or the emergence of the dependent variable. The dependent variable is the variable that is influenced or which is the result of the independent variable. The independent variable in this study is Corporate Social Responsibility (CSR), which consists of:

Community Support (X1), Diversity (X2), Employee Support (X3), Environment (X4), NonUS Operations / Not Only Operating in the Country of Origin (X5), and Product / Product (X6), while the dependent variable is the image of the company. The hypothetical model is as follows:

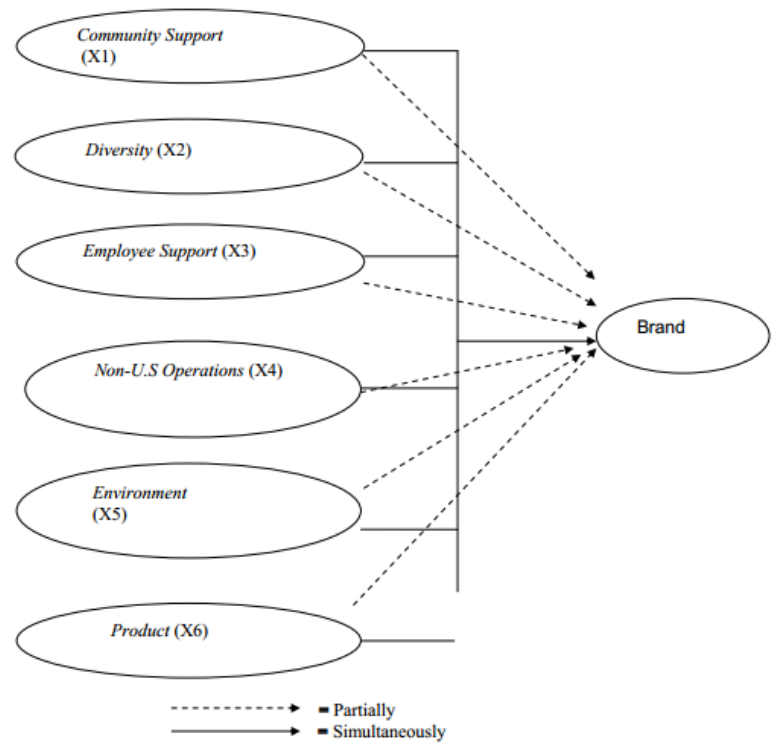

\section{Research Methodology}

In this study, I use a quantitative approach with survey research methods. According to Singarimbun in Singarimbun and Effendi (Ed. 1995: 3) survey research is research that takes a sample from a population and uses a questionnaire as the main data collection tool. The use of survey research methods is expected to obtain facts that cannot be observed, past information that has not been recorded and from the attitudes of respondents. Since this research is looking for the influence between variables through hypothesis testing, this research is an explanatory research. As for what is meant by explanatory research, according to Singarimbun in Singarimbun and Effendi (Ed. 1995: 5) is research that explains the causal relationship between variables using hypothesis testing. So in this study, hypothesis testing is a test of the influence between two or more variables, which is focused on explaining how much influence the independent variable has with the dependent variable.

This research was conducted on the recipients of the Morning and Night Toothbrush Movement (GERSIPAMA) CSR Program PT. Unilever collaborates with Spektra in Nganjuk Regency with a total of 200 people. The location of this research was chosen with various considerations, namely:

a. Whereas cases of toothache and cavities in East Java, including in Nganjuk Regency, were suffered by more than $75 \%$ of elementary school (SD) and Kindergarten (TK) children. The dangers caused are very large, such as accelerating the risk of stroke, heart disease, diabetes and premature babies (source: East Java Provincial Health Office).

b. Health education programs, especially those related to healthy behavior, are not much programmed or carried out by the Nganjuk Regency government. This occurs because of a lack of commitment and is not considered as an activity that must be prioritized because the Nganjuk Regency government still has to allocate the Regional Development and Expenditure Budget (APBD) in poverty alleviation efforts, where Nganjuk Regency is included in the 8 cities/districts with the highest poverty rates in East Java. In addition to the low purchasing power of the people. Due to limited budget allocations/funds in the health sector, the Nganjuk Regency government requested and withdrew various parties including PT. Unilever to help and provide its programs in Nganjuk Regency.

This study is using a sampling technique with non-probability sampling method. According to Sugiyono (2009: 218) nonprobability sampling is a sampling technique that does not provide equal opportunity/opportunity for each element or member of the population to be selected as a sample. The technique used is purposive sampling. Purposive sampling is a technique of sampling data sources with certain considerations (Sugiyono, 2009: 218). The characteristics of the respondents that the 
researcher determined were as follows:

1. Respondents are CSR program recipients who live in one of the 10 sub-districts in Nganjuk Regency that have been determined by PT. Unilever.

2. Respondents are elementary school teachers and Posyandu cadres.

3. Respondents aged 17 years and over, with the consideration that someone over the age of 17 is considered mature and able to think logically.

\section{Research Findings}

Based on the results of the analysis and discussion of the Effect of Corporate Social Responsibility on Image (Survey of Corporate Social Responsibility (CSR) Recipients of PT. Unilever Indonesia Collaborating with Spectra in the Form of Morning Night Toothbrush Movement in 10 Districts of Nganjuk Regency), the following findings can be drawn from the research :

1. Community Support, Diversity, Employee Support, Environment, Non US Operations/Not Only Operating in the Country of Origin and Products have a simultaneous and significant effect on the company's image, and most respondents agree that these six things influential in shaping the company's image.

2. Community Support, Diversity, Employee Support, Environment, Non US Operations/Not Only Operating in the Country of Origin and Products have a partial and significant impact on the company's image.

3. Diversity has a dominant influence on image companies, with a greater coefficient value when compared with the Community Support variable, Diversity, Employee Support, Environment, Non US Operations/ Not Only Operating in the Country of Origin and Products.

\section{Conclusion}

The conclusions that can be conveyed by the researcher with regard to this research are as follows:

1. Based on the research results, the Corporate Social program Responsibility (CSR) is a program that is considered good for Public. This is related to the existence of a Corporate
Social program Responsibility (CSR) that can even be accepted by the community create a positive image in society. Thus, PT. Unilever needs to maintain and develop a Corporate Social Responsibility (CSR) program that touches the interests of many parties.

2. Based on the research results, the implementation of Corporate Social Responsibility (CSR) in Nganjuk Regency needs to be expanded in scope from 10 SubDistricts to all Sub-Districts in Nganjuk Regency, so that the community will gradually emerge a sense of belonging to PT. Unilever. Therefore, is of the view that the company really cares about the community and creates a positive image for the wider community, especially throughout Nganjuk Regency.

3. Based on the research results, the Environment / Environment and Product variables in the company's Corporate Social Responsibility (CSR) program are further enhanced, so that the community understands and implements the program better and the community does not always depend on the company.

\section{References}

Arikunto, Suharsimi. 2002. Prosedur Penelitian, Suatu Pendekatan Praktek. Jakarta: PT. Rineka Cipta

Fajar, Mukti. 2010. Tanggung Jawab Sosial Perusahaan di Indonesia. Yogyakarta: Pustaka Pelajar

Hasan, Iqbal. 2002. Pokok-Pokok Metodologi Penelitian \& Aplikasinya. Jakarta: Ghalia Indonesia

http://id.wikipedia.org/wiki/Citra_perusahaan diakses 18 November 2010

http://id.wikipedia.org/wiki/kabupatennganjuk diakses 18 November 2010

http://www.bsr.org/BSR_CSR-Overviewbsr1.htm diakses 18 November 2010

http://www.MediaIndonesia.com diakses 21 Juli 2010

http://www.nganjukkab.go.id/index.php?option =com_content\&view $=$ article\&id $=$ 279:gersipama2010 diakses 18 November 2010 http:// www.sikatgigipagimalam.com/mengajakanak-untuk-selalu-menyikat-gigi diakses 18 November 2010

http://www.spektrasurabaya.com/joomla/index .php?option $=$ com_content\&view $=\mathrm{s}$ ection\&layout $=$ blog\&id $=5 \&$ Itemid $=53$ diakses 
The Effect Of Corporate Social Responsibility On Brand Awareness: The Case Study Of PT. Unilever Indonesia And Non-Governmental Organization (NGO) Spektra Surabaya Habibi Dinil Haq

18 November 2010

http://www.unilever.co.id/id/aboutus/ourhisto ry/?WT.LHNAV=Sejarah_kami diakses 18 November 2010

Jefkins, Frank. 1995. Public Relations. Alih bahasa Drs. Haris Munandar. Edisi keempat. Jakarta: Erlangga.

Mawarsari, Susi Dwi. 2006. Pengaruh Sikap Konsumen dalam Penerapan Program Corporate Social Responsibility terhadap Brand Loyalty Sabun Mandi Lifebuoy. Malang: Fakultas Ekonomi Universitas Brawijaya. Skripsi tidak Diterbitkan.

Murpratomo, Mochammad Anto. 2007. Persepsi Mahasiswa Akuntansi terhadap Corporate Social Responsibility. Malang: Fakultas Ekonomi Universitas Brawijaya. Skripsi tidak Diterbitkan.

Nazir. Moh 2003. Metode Penelitian. Bogor Selatan: Galia Indonesia

Sekaran, Uma 2006. Research Methods for Business 4th Ed. Alih bahasa Kwan Men Yon. Jakarta: Salemba

Sen, Shanker and Bhattacharya. 2001. Journal Of Marketing Research. 2001. Consumer Reaction to Corporate Social Responsibility, (online). http://www.extenza-eps.com/AMA/doi.jmkr.

Singarimbun, Masri dan Sofian Effendi, (Ed) 1995. Metode Penelitian Survai, Jakarta. : LP3ES

Soemirat, Soleh dan Elvinaro Ardianto. 2003. Dasar-Dasar Public Relations. Bandung: PT. Remaja Rosdakarya Offset

Solihin, Ismail. 2008. Corporate Social Responsibility. Jakarta: Salemba Empat.

Sugiyono, 2009. Metode Penelitian Kuantitatif dan Kualitatif dan RED. Bandung: Alfabeta

Untung, Hendrik. 2008. Corporate Social Responsibility. Jakarta: Sinar Grafika

Vinka, Aprianoo. 2009. Pengaruh Corporate Social Responsibility (CSR) terhadap Citra Perusahaan. Malang: Fakultas Ilmu Administrasi Universitas Brawijaya. Skripsi tidak Diterbitkan.

Wahyudi, Isa dan Busyro Azheri. 2008. Corporate Social Responsibility. Malang: In-Trans Institute.

Widayat dan Amirullah. 2002. Riset Bisnis. Edisi pertama. Yogyakarta: Graha Ilmu 